\title{
Effect of level of nitrogen fertilization and protein supplementation on herbage utilization by grazing dairy cows. 1. Herbage intake and feeding behaviour
}

\author{
JL Peyraud, L Astigarraga, P Faverdin, L Delaby, M Le Bars
}

INRA, Station de Recherches sur la Vache Laitière, 35590 Saint-Gilles, France

Three treatments were compared on a second cut of a perennial rye-grass pasture in a $3 \times 3$ latin square design using 9 fistulated dairy cows. Treatments consisted of 2 levels of $\mathrm{N}$ fertilization: $0-20$ (LN treatment) or $60-80 \mathrm{~kg} \mathrm{~N} / \mathrm{ha} \mathrm{(HN}$ treatment) before and after the first cut in spring 1992 , and of $2 \mathrm{~kg}$ a soyabean meal (1 kg protected cake) (SBM) supplementation when cows grazed the LN sward (LN + S treatment). The sward was strip grazed at a high daily herbage allowance of $28 \mathrm{~kg}$ OM/cow (cut by motor scythe). Each period lasted $14 \mathrm{~d}$. Daily herbage organic matter intake (HOMI) was estimated using chromic oxide to estimate faecal output and $\mathrm{N}$ and ADF contents in faecal OM for digestibility using the equation: digestibility $=0.791+0.0334$ $\mathrm{Nf}-0.0038 \mathrm{ADFf}\left(R^{2}=0.94\right.$, rsd [residual standard deviation] $=0.013$ ). All dung pats, marked by individual feeding coloured particles, were sampled each morning during the last $6 \mathrm{~d}$. Grazing time (GT) (at least 2 complete records/cow) and biting rate (BR) (number of bites during $2 \mathrm{~min}$ ) were recorded. Sward structure characteristics, rumen fermentation pattern, particle turnover rate

Table I. Herbage intake and feeding behaviour.

\begin{tabular}{lccc}
\hline & & $L N$ & $L N+S$ \\
& & & \\
& & & \\
HOMI (kg/d) & $16.2^{a}$ & $16.2^{\mathrm{a}}$ & 16.9 a \\
GT (min) & $515^{\mathrm{a}}$ & $509^{\mathrm{a}}$ & $500^{\mathrm{a}}$ \\
BR (n/min) & $41 \mathrm{a}$ & $45^{\mathrm{b}}$ & $43 \mathrm{ab}$ \\
Digestibility & $0.80^{\mathrm{a}}$ & $0.79^{\mathrm{a}}$ & $0.79 \mathrm{a}$
\end{tabular}

$a, b, c$ Means with different superscripts are different $(P<0.05)$. and DM soyabean hull degradability (as an index of celiulolytic activity) were measured.

HOMI, digestibility and milk production $(22.3 \mathrm{~kg} / \mathrm{d})$ were unaffected by lowering $\mathrm{N}$ fertilization (table 1). GT was unaffected and BR increased slightly in $L N$ swards $(P<0.05)$. These results may be explained by the moderate effect of $\mathrm{N}$ fertilization on herbage mass and sward structure. In particular, herbage mass still remained high in $\mathrm{LN}$ swards (3.94 vs 4.75 t OMha for $\mathrm{HN}$ ) and the proportions of green lamina (48\%) and sheath $(42 \%)$ were not affected.

Feeding concentrate did not depress HOMI and GT (table 1). These results contrast with the classical effects of feeding starchy concentrates at high herbage allowances (Meijs, 1986). This may be explained by no disturbance of rumen digestion due to the low level of SBM in the diet and/or the low degradation of protected SBM. Rumen $\mathrm{pH}(6.1)$, acidity $(110 \mathrm{mM} /)$, osmolality (320 mosmol//), cellulolytic activity $(0.53)$ and turnover rate $(5.0 \% / \mathrm{h})$ were unaffected by supplementation. Cows consumed $2.4 \mathrm{~kg}$ OM more in $\mathrm{LN}+\mathrm{S}$ treatment and milk yield $(25.1 \mathrm{~kg})$ was increased by $1.4 \mathrm{~kg} / \mathrm{kg}$ SBM.

HOMI showed large between-cow variations (14.3 to $18.4 \mathrm{~kg} \mathrm{OM} / \mathrm{d}$ ) which were related to the total number of grazing bites per day (TGB: 16.5 to $30.4 \times 10^{3} / \mathrm{d}$ ) and to the incisor arcade breath (IA: 8.4-9.7 cm): $\mathrm{HOMI}=10.8+0.028 \mathrm{TGB} \times \mid \mathrm{A}$; $r=0.91 ; \mathrm{rsd}=0.58 \mathrm{~kg} / \mathrm{c} / \mathrm{d}, n=9$.

In conclusion, herbage intake is not greatly affected by $\mathrm{N}$ fertilization and SBM supplementation, and so SBM is efficient to improve milk production at grazing.

Meijs JAC (1986) In: Grazing (J Frame, ed) BGS, occasional symposium $n^{\circ} 19$ 